\title{
Juxtaposing the Culture of Flood Disaster in Java Estuarine: Is It Political Commodification or Culture Naturalization?
}

\author{
Nevrettia Christantyawati \\ Faculty of Communications Science \\ Dr. Soetomo University \\ Surabaya, Indonesia \\ nevrettia.christantyawati@unitomo.ac.id
}

\author{
Tony Sukasah \\ Faculty of Communications Science \\ Dr. Soetomo University \\ Surabaya, Indonesia \\ Yenny \\ Faculty of Communications Science \\ Dr. Soetomo University \\ Surabaya, Indonesia
}

\begin{abstract}
Since two decades, the two estuarine of Java, Ciliwung River and Bengawan Solo Estuarine have been appeared as an ambiguity meaning of natural resource. On the first hand they mean as source of life that sustain the abundant living of the village. On the other hand, when the torrential rain occurs then it would be potential to trigger many other severe disasters. Ciliwung River streams to Jakarta while Bengawan Solo estuarine flows to many regions from Central Java to East Java. This article aims to contrasting how the local governments differently endeavor the flood risk as political commodification or cultural naturalization. The research has been conducted using discourse analysis by scrutinizing two different videos issued by the Public Relations of district government which one depicts the successful district government in stimulating people's resiliency of river bank. On a contrary, the video which represents the newly-elected governor of Jakarta may lead to an extravaganza challenge by defeating the flood in order to win public trust. The findings indicate the contrast culture of public resiliency and culture of political image construction. Nevertheless, the discourse about flood disaster turns to be a political contestation to raise many critics from the public rather than constructing resiliency. Hence, this contrast culture of risk and disaster may result in different political and cultural framework to endeavor best effort of reducing risk disaster in many regions and cities in Indonesia.
\end{abstract}

Keywords-culture of public resiliency; risk naturalization; political image; flood disaster commodification; culture of disaster challenge

\section{INTRODUCTION}

This article discusses the comparison of the cultural distinction of flood mitigating in two regions. These two distinctive cultural flood risk mitigating are obviously juxtaposition to the different meaning of flood disaster. Although it is merely distinct to each other, but there is found similarity about the goal attachment embedded by each government. This may lead us to raise the question issue if this is all about a political commodification or just culture naturalization. Furthermore, the finding tremendously enhances the meaning of natural disaster causing by water, rain and flood in both regions.

The research was conduct in two regions where the sites are frequently submerged by flood during the torrential rain. The first region is Ciliwung river stream flow to Jakarta the capital city which consists of many environmental drawbacks. Alongside the riverbank is poorly crowded by slums and nearly become a shantytown. If the governor of Jakarta had not acted promptly to recover and to revive this Ciliwung riverbank, the exacerbation of flood inundation would reach at peak in the torrential rain season. The second region one is Bengawan Solo Estuarine which contains high risk of flash flood. This Estuarine has the longest river with creeks, streams and wetlands in Java Island. Also, it is enormously potential to submerge thousands of houses, several villages, vast rice field area and also provincial highway road. The Bengawan Solo River has been the main focus of many researches about hydrology, civil engineering and other geo-science to observe the water flow. On the other hand, social sciences scrutinize the social impact of the people who live alongside the riverbank. This article is about to explain the socio-cultural paradigm to generate the juxtaposition in which political and cultural endeavor are embedded.

The aim is to contrasting how the local governments differently endeavor the flood risk as political commodification or cultural naturalization. The research has been conducted using discourse analysis by scrutinizing two different videos issued by the Public Relations of district government which one depicts the successful district government in stimulating people's resiliency of river bank. On a contrary, the video which represents the newly-elected governor of Jakarta may lead to an extravaganza challenge by defeating the flood in order to win public trust.

\section{METHODOLOGY}

\section{A. Critical Discourse Analysis}

First, the research methodology implements the discourse analysis by Norman Fairclough that scrutinize the relation between micro textual and macro social context. To some extent, this model enormously enhances how the language is utilized as power practice. The analysis focuses on how the language is constructed by social relation and certain social context [1]. 
TABLE I.

FAIRCLOUGH‘s CRITICAL DISCOURSE ANALYSIS MODEL

\begin{tabular}{|l|c|}
\hline \multicolumn{1}{|c|}{ elements } & Points of observation \\
\hline Representation & $\begin{array}{c}\text { How the event, people, groups, situation, facts or } \\
\text { whatever objects are described. }\end{array}$ \\
\hline Relation & $\begin{array}{c}\text { How the relations amid people, public, journalists and } \\
\text { participant are described }\end{array}$ \\
\hline Identity & $\begin{array}{c}\text { How the media identity, public, audience and participant } \\
\text { are told in the story. }\end{array}$ \\
\hline \multicolumn{2}{|c|}{ N. Fairclough, Discourse and Social Change, vol. 54. 1992. [1] }
\end{tabular}

This model confirms that texts lead across time and space to enhance how the three elements construct the social change. To be brief, the explanation of this model will pass through three levels which are, micro level, meso level, and macro level. To figure out the complete finding, this article has examined the texts from two sources. First source are the short videos issued by Bojonegoro District Official Public Relation [2] and a short one posted by Jakarta Official Public Relation [3]. The second source is a short video broadcast by private television, Metro TV as part of citizen journalism which depict the social problems [4] and an environmental virtual graphic news which simulate the situational problem [5]. Furthermore, the dissection of the corpus is organized as an opposition binary group. What would the official Public Relation of both regions narrate on the videos? In contrast, how would the media address the issue.

\section{DISCUSSION}

\section{A. Flood, Ciliwung and Jakarta Capital City}

The complex portrayal of Jakarta contains many issues due to poverty, slums, chronic urban flood, environmental degradation and many other societal risk and hazards. These multicomplex problems lead to a difficulty problem solving. The problems deal with poverty and flooding are exacerbation problems that particular person in charge is expected to act quickly to find the solution point. The main challenge of any Governor, who had occupied or will be elected is to improve the welfare of the most citizen. The most urgent program to improve this calamity is to normalization and combat river flogging by debris and waste. This river bank has been poorly decreasing of inferior quality along with the growing number of people. The level of occupancy that followed the growing population increasingly lead the condition of residential look very shabby with semi-permanent house made of wood. It might be potential to grow the crowded shantytown along the river bank.

The video that released by the official Public Relation Department of Jakarta Government depicts shortly about what the tremendous efforts which the Government conduct to relieve this trouble and reducing flood risk and enhance the quality of environment. No additional explanation and narrating story in this video except depicting the progress of this river recovery project. On contrast, the video which is issued by media describe the contrary. Many calamities and drawbacks are rose and addressing the responsibilities. The main figures depict in those audio-visual materials are the predecessor governors compare to the present one. This means that the whole society in Jakarta meet the demand to diminish and overcome environmental problems. A study conducted by
Van Vroost [6] revealed that Jakarta flooding consists of many political issues rather than political ones. Moreover, the cycle of flooding related to the political issue of newly elected Governor. This indicates the oxymoron of instrumental assessment to scrutinize the Governor's setbacks. Unless, the Governor himself maintain good communication amid his staffs and men, strong relationship with the media, and extremely outstanding leadership.

The relations that Governor of Jakarta, Anis Baswedan and his vice Governor, Sandiaga Uno, have got through pretty well amid the stake holders. Certainly, this may lead the public to figure out the how both of them will be able to tackle the environmental problem standing for their relations. Some are skeptic while the other are optimists.

Finally, the identity that Jakarta Governor, public audience and participant are described as a mega-city combat poverty and extremely challenge whoever the leader to decrease the societal problem, poverty, environmental degradation, overpopulated area, slums eradication and crime reduction. So that, the identity of Jakarta and its leader reflects the Indonesian complex urban living.

\section{B. Rural area flooding and the claims of succesful Bojonegoro Regent}

As a juxtaposition, how the regent of Bojonegoro who is in charge to lead rural area that prone of high risk flood has succeed to overcome the big flood. This claim was narrated in the short video issued by Public Relations of Bojonegoro regent. The story told about how the regent implemented the flood mitigation and decreasing damage and victims due to flood. The big flood that use to inundate the rural area reciprocally occurs during the heavy rain seasons when the water level of Bengawan Solo Estuarine escalate the red level.

The program which the regent implement is called “Evakuasi Banjir Bahagia” or Happy Flood Evacuation that the motto is harmony living with the disaster[6]. This program is aimed to evacuate the villagers, children and women and also the living-stocks. He built a home shelter which then called happy garden-yard evacuation compliment with public kitchen, intimate rooms for couples who need having sex, study area and large barracks with plenty mattresses. Related to this, it maintains the public security and very nice comfortability in the chaotic situation. After all, the refugees never feel worry and unsafe because the regent guarantees their needs during the flood. This is probably the main cause that Bojonegoro people are always happy when the flood occurs and also another upcoming disaster [7].

The representation in the video shows how the people of Bojonegoro live harmony forever with the threat of flood. Even though they live on the river bank, with low number of economic income and average level of education, these people refuse to be relocated since they feel this is a safe home [7]. The video also represents how the regent supports the villagers to evacuate and keep their living-stocks safe in a large cage. Thus, the whole representation illustrates the living harmony with the overflowing water resource. 
After that, the relation amid the local governor, persons in charge of many municipality institutions and other social components, shows the good, rigorous and solid networking to overcome the crises. This kind of relationship was focus on how the regent acts during the flood to soothe the calamities, to provide every single detail of tools and instruments to handle the difficult situation [2].

In the end, the narrative tells the compliment of nice and delicious food that the public kitchen officers serve for the refugee, as if as they were having meal in a restaurant. This identity was constructed that even tough the refugees are in difficult situation they can smile happily to live harmony with the danger of flood. The strong identity enhances the culture of having meal and sharing food is more important, as a clue to be survive in a crisis. The Bojonegoro villagers also has a ritual of mass sharing food and having meal tradition which they call "manganan" after the harvest consecutively. By this cultural factor, the regent enhances the social identity to build the resilience and tough people.

\section{CONCLUSION}

To conclude, both video narrative tells the contradictive story about the leaders in action to overcome the similar crises. On the other hand, Jakarta as a capital city represents the image of part of Indonesian metropolitan cities. Also, the governor and other municipalities who are in charge are politically indicator of the credibility and tough leadership to face chaotic. People are judging on him, many media are keeping an eye on him, the political rivalry are scrutinizing for something the governor might doing wrong. In that case, the enhance of risk communication is still on the leadership. When this happens only how to magnifying the image of leadership tackling the problem, there might be a disparity of focusing on the people in trouble.

In a contrary, what happened to Bojonegoro region distinguish from Jakarta. In rural area, where people keep maintaining the good relationship of other, the communitybased resilience is tough enough to face the flood threats. Combining with strong relationship among the regent, the local media and many institutions, the Bojonegoro regent achieve the highest award and excellent recognition as one of reputable regent. The official video that issued by Public Relations Bojonegoro Region has delivered message that the fact is true, even some ideas are sound very silly such as evacuating firstly the living stocks rather than their wives and children. The focus of this case is enhancing the people's actions and the regent support. Moreover, the basic risk communication is enacted, the regent has built strong credibility and good relationships and good coordination to act effectively. This empirically method may lead to a better solution to increase the people resiliency.

Perhaps the capital city is an overpopulated area, there are multi complex societal problems that the governor should diminish. The challenge of eradication this disaster impact is not very easy. It is necessary to employ the good plans. Eventually, good communication, good coordination and rapid decision and action are indispensable in this case.

\section{REFERENCES}

[1] N. Fairclough, Discourse and Social Change, vol. 54. 1992.

[2] Humas Kabupaten Bojonegoro, "Bojonegoro - Bojonegoro Harmonis Dengan Banjir [Bojonegoro - Bojonegoro in Harmony with the Flood]," Lisensi YouTube Standar, 2015. [Online]. Available: https://www.youtube.com/watch?v=Ivbl6Gr3myE.

[3] T. PSA, "Penangangan Banjir di Jakarta (PSA) [Flood Management in Jakarta (PSA)],” Lisensi YouTube Standar, 2016. [Online]. Available: https://www.youtube.com/watch?v=EqhtCXOZQjs.

[4] A. Trifiana, "Potret Warga Tepi Sungai Ciliwung [Portrait of People at the Bank of Ciliwung River],” Metro TV Wide Shot, Indonesia, 2013.

[5] Metro TV, "Banjir Jakarta dari Tahun ke Tahun [Jakarta Floods from Year to Year]," Metro TV News, Indonesia.

[6] R. Van Voorst, "Applying the risk society thesis within the context of flood risk and poverty in Jakarta, Indonesia,” Heal. Risk Soc., vol. 17, no. 3-4, pp. 246-262, 2015.

[7] D. S. W. Laraswati and P. Bambang, "Kajian Tentang Penyebab Masyarakat Memilih Tetap Bermukim di Wilayah Rawan Banjir (Studi Kasus di Kelurahan Ledok Wetan Kecamatan Bojonegoro Kabupaten Bojonegoro) [Study about the Cause of People who Stays in the Flood Prone Area (Case Study of Ledok Wetan Sub-district, Bojonegoro District, Bojonegoro Regency)],” Swara Bhumi, vol. 3, October 2014. 